\title{
$\mathrm{LR}=$ INTERNATIONAL JOURNAL OF ACADEMIC

\section{Performance Evaluation of Islamic Unit Trust by Adapting Value at Risk: Some Evidence}

Farah Azaliney Mohd Amin, Nurul Aziera Saim, Sharifah Izzatul Farhanah Syed Putera, Siti Nurul Ain Alwi

To Link this Article: http://dx.doi.org/10.6007/IJARAFMS/v11-i1/7725

DOI:10.6007/IJARAFMS /v11-i1/7725

Received: 10 January 2021, Revised: 11 February 2021, Accepted: 29 February 2021

Published Online: 16 March 2021

In-Text Citation: (Amin et al., 2021)

To Cite this Article: Amin, F. A. M., Saim, N. A., Putera, S. I. F. S., \& Alwi, S. N. A. (2021). Performance Evaluation of Islamic Unit Trust by Adapting Value at Risk: Some Evidence. International Journal of Academic Research in Business and Social Sciences, 11(1), 91-98.

\section{Copyright: (c) 2021 The Author(s)}

Published by Human Resource Management Academic Research Society (www.hrmars.com)

This article is published under the Creative Commons Attribution (CC BY 4.0) license. Anyone may reproduce, distribute, translate and create derivative works of this article (for both commercial and non-commercial purposes), subject to full attribution to the original publication and authors. The full terms of this license may be seen

at: http://creativecommons.org/licences/by/4.0/legalcode

\section{Vol. 11, No. 1, 2021, Pg. 91 - 98}

Full Terms \& Conditions of access and use can be found at http://hrmars.com/index.php/pages/detail/publication-ethics 


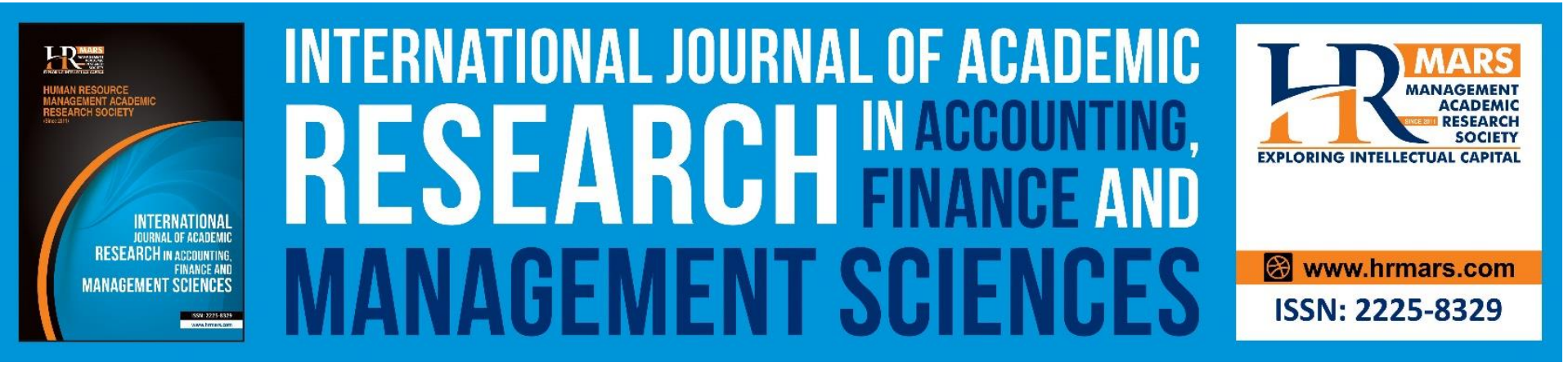

\title{
Performance Evaluation of Islamic Unit Trust by Adapting Value at Risk: Some Evidence
}

\section{Farah Azaliney Mohd Amin, Nurul Aziera Saim, Sharifah Izzatul Farhanah Syed Putera, Siti Nurul Ain Alwi}

Faculty of Computer and Mathematical Sciences, Universiti Teknologi MARA Cawangan Negeri Sembilan, Kampus Seremban, Malaysia

Email: farah525@uitm.edu.my

\begin{abstract}
Previously, a set of standard measures such as Sharpe, Treynor and Jensen's Alpha are widely used to evaluate the overall fund performance. However, the performance measures that consider beta or standard deviation as their risk variable might not be very useful for investors. In the present study, a performance measurement technique that considers only downside risk, known as VaR-adjusted Sharpe is proposed. Hence, the objective of this study is to evaluate and rank the CIMB Islamic equity funds from 2016 to 2019 based on four performance measures relative to the Kuala Lumpur Composite Index $(\mathrm{KLCl})$ as the benchmark. The results of the study proved that by adapting VaR in Sharpe has successfully evaluated the performance of selected Islamic funds because the ranking obtained is consistent with the ranking based on the standard Sharpe.
\end{abstract}

Keywords: Islamic Unit Trust, Sharpe, Treynor, Jensen's Alpha, Value at Risk.

\section{Introduction}

Globally, there are almost 2 billion Muslims from 7.6 billion people in the world. Due to their religious beliefs, this enormous market of Muslims is not only actively seeking trusted and certified Halal sources for food, cosmetics, home care, pharmaceuticals and daily products but also for investment products (Bakar et al., 2019). Therefore, it has prompted the local government to introduce various Shariah-compliance investment products to fulfill the demand from its Muslim investors. One of the most popular products is unit trust funds that comply with Islamic investment principles as revealed in the Quran and Sunnah. This is because unit trust is an affordable avenue for small investors to enjoy a professionally managed investment fund with a reasonable level of diversification, liquidity and risk minimization (Abdullah et al., 2012).

There are various types of funds in the Malaysian capital market such as money market funds, bond funds, equity funds and balanced funds (a mix of bonds, equity and money market instruments). Observed that, each fund has a different profile in terms of risk and return whereby high risk usually indicates a high return on investment. Generally, money market funds also known as money market mutual funds are risk-free investment are the lowest risk funds, while equity funds are the highest 
INTERNATIONAL JOURNAL OF ACADEMIC RESEARCH IN ACCOUNTING, FINANCE AND

MANAGEMENT SCIENCES

Vol. 11, No. 1, 2021, E-ISSN: 2225-8329 @ 2021 HRMARS

risk funds. Due to the absence of Islamic unit trust funds, this study focuses on Shariah-based funds that depend solely on the equity market to cater the need especially from Muslim investors.

\section{Problem Statement}

Over the years, numerous studies have utilized the standard framework consist of Sharpe, Treynor and Jensen's Alpha to evaluate the overall performance of a fund. Due to the volatility of the unit trust environment has made risk measurement an important aspect in evaluating the performance of a fund for both domestic and international markets. It can be observed that Sharpe ratio uses the fund's standard deviation, while Treynor and Jensen's Alpha employ beta as their risk variable. Initially, the standard deviation of returns that is used to describe the total risk does not only penalize the downward volatility (losses) but also the upward volatility (profits). Moreover, the beta coefficient which measures the volatility of a fund in relation to the changes in the market also becomes less meaningful for long-term investments such as unit trusts. Thus, the risk variables used previously might not be consistent with the investor's perception that wishes to minimize only the negative volatility (Jamaan et al., 2011). Therefore, smart investors need a suitable performance evaluation to select the appropriate funds for their portfolio based on their risk appetite and investment objective.

\section{Contribution of The Study}

In recent years, Value at Risk (VaR) has become a popular instrument among bankers and portfolio managers not only as a risk measurement method but also helps investment managers (Cabedo \& Moya, 2003; Alexander \& Baptista, 2003). Statistically, VaR is of interest because it can summarize the downside of the market risk (the expected loss associated with price movements) under normal market conditions over a specific time interval at a given confidence level (Jorion, 2007; Amin et al., 2018). Although VaR has been widely accepted as a true risk measure for the banking industry, it is yet to find enough acceptances for the investment industry (Deb \& Banerjee, 2009). Hence, the current study attempt to fill the gap regarding performance measurement technique concerning VaR estimation, an aspect which is completely ignored for performance reporting in the Malaysian unit trust industry.

The objective of this study is therefore to evaluate and rank the performance of the CIMB Islamic equity funds based on the following theoretical models: Sharpe, Treynor, Jensen's Alpha and the proposed VaR-adjusted Sharpe ratio relative to the Kuala Lumpur Composite Index ( $\mathrm{KLCl}$ ) as the benchmark. The result of this study will be useful not only to Muslim investors but generally any market participants such as fund managers and investment companies that want to consider Islamic unit trust funds in their investment portfolio.

\section{Literature Review}

There is a large and growing body of literature that has investigated the overall performance of the Malaysian unit trust industry since 1980s. Historically, empirical findings revealed that on average the local unit trust funds were unable to outperform its market benchmark (Shamser \& Annuar, 1995; Taib \& Isa, 2007). Low (2007) emphasizes that it is important for both investment companies as well as fund managers to select the most appropriate market benchmark since it should reflect the investment characteristics of the evaluated fund. Hence, several local indices were commonly 
employed by researchers to provide a sound comparison of performance between the funds and their respective benchmarks, namely the Kuala Lumpur Composite Index (KLCl), Kuala Lumpur Emas Index (EMAS), RHB Islamic Index or Kuala Lumpur Shariah Index (KLSI).

It is reported that the first Islamic fund in Malaysia was Tabung Amanah Bakti by Asia Unit Trust Berhad in 1971, but the first official Islamic mutual fund was launched in 1993, namely Tabung Ittikal Arab-Malaysian, managed by Arab-Malaysian Unit Trust Bhd (Mansor \& Bhatti, 2011). Since the funds are relatively new and its development was improving with time, much of the literature examined the performance of Islamic unit trust funds in comparison with Conventional trust funds. A comprehensive study was done by Mansor and Bhatti (2011) that used monthly aggregate returns from 1996 to 2009 to evaluate the performance of the 350 Conventional and 128 Islamic mutual funds in Malaysia. Their findings reveal that Islamic funds failed to outperform Conventional funds during the observed period. Indirectly, it also indicates that the average return performance of the Islamic mutual funds is lower than the average return of the Conventional funds (Bashir \& Nawang, 2011; Elfakhani et al., 2005).

The similar findings were also found in the recent studies of Suhana et al. (2012) and Norman et al. (2013) that employed Sharpe, Treynor and Jensen index as the basis for their analysis. Suhana et al. (2012) assess the performance analysis of four Islamic unit trust funds: RHB Mudharabah Fund, MAAKL Syariah Index Fund, PRUdana Al-Illham and AIIMN Growth Fund and four conventional unit trust funds: RHB Capital, MAAKL Value Fund, PRU Small-Cap Fund and Select Income Fund are measured in comparison with KLCl. Later, Norman et al (2013) focus on seven Conventional equity funds and seven Shariah-based equity funds of Public Mutual Berhad. Benchmarks used in this study are FTSE Bursa Malaysia KLCI (FBM KLCl) for conventional funds, FTSE Bursa Malaysia EMAS Shariah Index (FBMS) for Shariah-based funds as a benchmark. Collectively, their findings were consistent with previous findings reveal that Islamic funds performed better than the Conventional funds during bearish (bad) economic trends, and vice versa during bullish (good) economic conditions. Hence, the Islamic fund is a good hedging investment, especially against market downturns (Abdullah et al., 2007; Fikriyah et al., 2007).

There are relatively few historical studies in the area of performance measurement technique concerning VaR estimation. For example, Feng (2008) compared the traditional Sharpe with standard deviation as risk variable with the VaR as a substitute for a standard deviation to find the better performance of Chinese mutual funds. While, other study by Tehrani et al., (2014) measure the performance evaluation of Iranian mutual funds. Consistent with Feng's findings, Tehrani et al. [23] also conclude that the standard deviation of traditional Sharpe can be substituted with VaR. Hence, this study attempts to widen the existing literature by employing VaR as the risk variable to examine the performance of selected Islamic unit trust funds in the context of Malaysia.

\section{Methodology \\ Data Collection}

The sample of this study consist of five CIMB Islamic equity funds which are Al-Azzam Equity Fund, DALI Equity Growth Fund, Equity Aggressive Fund, Small Cap Fund and Principal DALI Opportunities Fund. This study uses historical data of daily Net Asset Value (NAV) for three years obtained from the CIMB Principal Asset Management Berhad's website, https://www.principal.com.my/ starting from September 2016 to August 2019. This study utilized the 
four performance measures consist of Sharpe, Treynor, Jensen's Alpha and VaR-adjusted Sharpe. These models were then used for evaluating and ranking of the selected Islamic unit trust funds. The Kuala Lumpur Composite Index $(\mathrm{KLCl})$ is chosen as a proxy for the market return in Malaysia and the risk-free rate was obtained from Malaysian Treasury Bills for 3 years.

\section{Measurement of Performance}

The first measure is Sharpe ratio which uses the fund's standard deviation to evaluate overall performance of a fund by considering the total risk. A fund would be regarded as a good investment if there is less risk involved to generate returns. Therefore, higher ratio would indicate the better performance (Sharpe, 1966). The standard Sharpe (designated S) which divides the excess returns (fund return minus risk-free rate) by its standard deviation as the risk variable is stated as follows:

$$
S=\frac{R_{i}-R_{f}}{\sigma_{i}}
$$

where $R_{i}=$ Average return of fund $i, R_{f}=$ Average return on Malaysian Treasury Bills and $=$ Standard deviation of return for fund $i$.

In contrast, the second performance measure by Treynor (1965) seeks to evaluate the fund's performance by only considering the systematic risk. Beta will measure the sensitivity of the fund in relation to the changes in the market such as inflation risk. As a result, the higher the Treynor ratio, the more desirable the fund. The Treynor (designated $T$ ) which divides the excess return by beta as the risk variable is calculated using the equation below:

$$
T=\frac{R_{i}-R_{f}}{\beta_{i}}
$$

where $R_{i}=$ Average return of fund $i, R_{f}=$ Average return on Malaysian Treasury Bills and $=$ Beta coefficient of return for fund $i$.

The third approach and the most widely used is Jensen's Alpha (designated $\alpha$ ) was developed based on the Capital Asset Pricing Model (CAPM) by Michael C. Jensen in 1968. Jensen emphasizes that in estimating $\alpha$ which is the intercept of a regression line of the excess return of the fund on the excess return of a market benchmark is evaluated by using the equation below:

$$
\alpha=\left(R_{i}-R_{f}\right)-\beta_{i}\left(R_{m}-R_{f}\right)
$$

where $R_{i}=$ Average return of fund $i, R_{f}=$ Average return on Malaysian Treasury Bills, $\beta_{i}=$ Beta coefficient of return for fund $i$ and $R_{m}=$ Average return on KLSE Composite Index for the period under study. Theoretically, the alpha value would indicate whether the performance of a fund is superior or otherwise. Note that, the positive alpha would indicate that the fund achieves excess return relative to the market, and vice versa. Hence, the higher the ratio is better (Jensen, 1968). 
INTERNATIONAL JOURNAL OF ACADEMIC RESEARCH IN ACCOUNTING, FINANCE AND MANAGEMENT SCIENCES

Vol. 11, No. 1, 2021, E-ISSN: $2225-8329$ @ 2021 HRMARS

Finally, Alexander and Baptista (2003) found that funds' performance can be measured by using Value at Risk (VaR) which it replaces the standard deviation that previously used in Sharpe ratio. The VaR-Adjusted Sharpe ratio (designated $S_{V a R}$ ) given as:

$$
S_{\text {VaR }}=\frac{R_{i}-R_{f}}{\operatorname{VaR}_{i}}
$$

where $R_{i}=$ Average return of fund $i, R_{f}=$ Average return on Malaysian Treasury Bills and $\operatorname{VaR}_{i}=$ Value at Risk of fund $i$.

\section{Results and Discussions}

Table 1 below show the summary of the performance measurement for the selected CIMB Islamic equity funds using Sharpe, Treynor, Jensen's Alpha and the proposed, VaR-adjusted Sharpe relative to $\mathrm{KLCl}$ as the chosen market index. The CIMB Islamic funds were then ranked according to their performance. $\mathrm{KLCl}$ is the main index of Kuala Lumpur Stock Exchange (KLSE) that composed of the top 30 companies on the Bursa Malaysia Exchange.

Table 1: Ranking of Selected CIMB Islamic Equity Funds

\begin{tabular}{ccccccccc}
\hline \multirow{2}{*}{ Funds } & \multicolumn{2}{c}{ Sharpe } & \multicolumn{2}{c}{ Treynor } & \multicolumn{2}{c}{ Jensen's Alpha } & \multicolumn{2}{c}{$\begin{array}{c}\text { VaR-adjusted } \\
\text { Sharpe }\end{array}$} \\
\cline { 2 - 9 } & Ratio & Rank & Ratio & Rank & Ratio & Rank & Ratio & Rank \\
\hline Al-Azzam Equity & -4.3797 & 4 & -3.7375 & 2 & -0.4845 & 2 & -0.1815 & 4 \\
Equity Aggressive & -4.1841 & 3 & -3.6106 & 1 & -0.3751 & 1 & -0.1788 & 3 \\
$\quad$ Small Cap & -1.5095 & 2 & -4.0578 & 4 & -0.6895 & 4 & -0.1299 & 2 \\
DALI Equity Growth & -1.0092 & 1 & -8.9236 & 5 & -4.1606 & 5 & -0.0229 & 1 \\
Principal DALI & -5.0476 & 5 & -3.9436 & 3 & -0.6261 & 3 & -0.2195 & 5 \\
Opportunities & & & & & & & & \\
\hline FTSE KLCI & -5.6435 & & -3.1671 & & 0 & & -0.2174 \\
\hline
\end{tabular}

The results of the Sharpe measures indicate that all CIMB Islamic unit trust funds outperformed the domestic market index, $\mathrm{KLCl}$ which is -5.6435 . Observed that, the most performing fund is DALI equity Growth and the lowest performing fund is Principal DALI Opportunities with a ratio of -5.0476 and -1.0092 respectively. However, it is important to note that Sharpe measures the total risk which includes systematic and unsystematic risks.

As for Treynor ratio, all funds had negative results ranged from -8.9236 to -3.6106 . However, the fund with the highest performing funds was Equity Aggressive and the lowest performing funds was DALI Equity Growth with a ratio of -3.6106 and -8.9236 respectively. In contrast to Sharpe, the empirical findings of Treynor show that all funds underperformed $\mathrm{KLCl}$ since the ratio for each fund in the CIMB unit trust was below the Treynor measure of $\mathrm{KLCl},-3.1671$.

This study also found that the alpha based on the Jensen's Alpha have negative value ranging from -4.1606 to -0.3751 for all the funds. This is a sign that all the observed fund is having negative return (loss). Furthermore, all the alphas of the funds were observed lower than the domestic 
benchmark alpha. As a result, the CIMB Islamic unit trust funds also underperformed the $\mathrm{KLCl}$ when measured by the Jensen's Alpha. The similar result of Treynor and Jensen's Alpha are due to both performance measure only considers the systematic risk that is non-diversifiable.

Finally, this study employs a Value at Risk as a risk variable and known as VaR-adjusted Sharpe. This proposed performance measure which uses the fund's maximum expected loss rather than just the fund's standard deviation (total loss) in Sharpe. As reported in Table 1, the result of VaR-adjusted Sharpe shows that all the funds have negative ratio ranging from -0.2195 to -0.0229 . In addition, it also indicates that only one fund (Principal DALI Opportunities) underperformed the market index, $\mathrm{KLCl}$ with -0.2174 . Observed that, the result of the most and the lowest performing fund which is DALI Equity Growth and Principal DALI Opportunities, respectively is found to be consistent with the results from previous standard Sharpe.

Overall, the results were mixed where Islamic unit trust funds were found to underperformed the local index when measured by the Treynor and Jensen's Alpha ratios but not when the Sharpe ratio was applied. In terms of ranking, the overall results show that Treynor performance measure rank funds in accordance to the ranking of Jensen's Alpha. While, Sharpe performance measure rank funds in accordance to the ranking of VaR-adjusted Sharpe. The inconsistency of ranking relative to performance measure of five selected Islamic unit trust might have been caused by the different types of risk variable used in each measures. Moreover, the finding of this study also shows that the proposed method, VaR-adjusted Sharpe is able to identify the inferior and superior funds, thus making it an alternative to use when investment decisions need to be made.

\section{Conclusion}

The objective of this study is to examine the performance of five selected CIMB unit trust funds from the year 2016 to 2019. Four performance measures are utilized, namely, the Sharpe, Treynor, Jensen's Alpha and VaR-adjusted Sharpe ratios. The main finding revealed that the overall performance measurement for CIMB Islamic equity funds is below the market index, $\mathrm{KLCl}$. In addition, the rankings based on four performance measures revealed that the rankings are consistent if the measurement used same particular risk variables. The finding of this study also provides a significant evidence that VaR-adjusted Sharpe has successfully evaluated the performance of selected funds since the ranking obtained is consistent by performing standard Sharpe. Therefore, the findings might contribute towards making informed investment decisions in the context of Islamic unit trust in Malaysia, without undertaking time-consuming analysis.

\section{References}

Abdullah, L., Noor, N. M. M., \& Amin, W. A. A. W. M. (2012). Unit Trust Forecasting using Adaptive Neural Fuzzy Inference System: A Performance Comparison. Procedia-Social and Behavioral Sciences, 57, 132-139.

Abdullah, F., Hassan, T., \& Mohamad, S. (2007). Investigation of Performance of Malaysian Islamic Unit Trust Funds. Managerial Finance, 33, 142.

Amin, F. A. M., Yahya, S. F., Ibrahim, S. A. S., \& Kamari, M. S. M. (2018). Portfolio Risk Measurement Based on Value at Risk (VaR). AIP Conference Proceedings, 1974(1), 020012. AIP Publishing LLC.

Alexander, G. J., \& Baptista, A. M. (2003). Portfolio Performance Evaluation Using Value at Risk. The Journal of Portfolio Management, 29(4), 93-102. 
INTERNATIONAL JOURNAL OF ACADEMIC RESEARCH IN ACCOUNTING, FINANCE AND

MANAGEMENT SCIENCES

Vol. 11, No. 1, 2021, E-ISSN: 2225-8329 @ 2021 HRMARS

Bashir, M. S., \& Nawang, W. R. W. (2011). Islamic and Conventional Unit Trusts in Malaysia: A Performance Comparison. Journal of Islamic Economics, Banking and Finance, 7(4).

Bakar, A. N., Jaafar, H. S., Matulidi, N., Alam, S., \& Alam, P. (2019). Assessment of Halal Governance Issues in Malaysia. Insight Journal (IJ), 5, 1-8.

Cabedo, J. D., \& Moya, I. (2003). Estimating Oil Price 'Value at Risk' using the Historical Simulation Approach. Energy Economics, 25(3), 239-253.

Deb, S. G., \& Banerjee, A. (2009). Downside Risk Analysis of Indian Equity Mutual Funds: A Value at Risk Approach. International Research Journal of Finance and Economics, 23, 216-230.

Elfakhani, S., Hasan, M. K., \& Sidani, Y. (2005). Comparative Performance of Islamic versus Secular Mutual Funds. Paper presented at the 12th Economic Research Forum, University of New Orleans, US.

Feng, J. (2008). Evaluation The Performance of Chinese Mutual Funds: A Study of the Application of Value-at-Risk. (Unpublished Master's Thesis), University of Nottingham, Ningbo, China.

Fikriyah, A., Taufiq, H., \& Shamsher, M. (2007). Investigation of Performance of Malaysian Islamic Unit Trust Funds: Comparison with Conventional Unit Trust Funds. Managerial Finance, 33(2), 142-153.

Jamaan, S. H., Weng, H. L., \& Isa, Z. (2011). Different Downside Risk Approaches in Portfolio Optimisation. Journal of Quality Measurement and Analysis, 7(1), 77-84.

Jorion, P. (2007). Value at Risk: The New Benchmark for Managing Financial Risk (3rd ed.). NY: McGraw-Hill Companies.

Jensen, M. C. (1968). The Performance of Mutual Funds in the Period 1945-1964. The Journal of Finance, 23(2), 389-416.

Mansor, F., \& Bhatti, M. I. (2011). Risk and Return Analysis on Performance of the Islamic Mutual Funds: Evidence from Malaysia. Global Economy and Finance Journal, 4(1), 19-31.

Norman, N., Almsafir, M. K., \& Smadi, A. (2013). Comparative Study of Conventional and Shariah Based Unit Trust Funds Performance of Public Mutual Berhad. Australian Journal of Basic and Applied Sciences, 7(9), 354-363.

Sharpe, W. F. (1966). Mutual Fund Performance. Journal of Business, 39(1), 119-138.

Suhana, M., Zuraidah, R., Nooririnah, O., Ruziah, A. L., \& Zaibedah, Z. (2012). Performance Analysis on Islamic Unit Trust. International Conference of Technology Management, Business and Entrepreneurship (ICTMBE2012), 643-655.

Taib, F. M., \& Isa, M. (2007). Malaysian Unit Trust Aggregate Performance. Managerial Finance, 33, 102.

Low, S. W. (2007). Malaysian Unit Trust Funds' Performance During Up and Down Market Conditions: A Comparison of Market Benchmark. Managerial Finance, 33, 154-166.

Shamsher, M., \& Annuar, M. N. (1995). The Performance of Unit Trusts in Malaysia: Some Evidence. Capital Market Review, 3.

Tehrani, R., Mohammadi, S. M., \& Nejadolhosseini, N. S. (2014). Value at Risk as a Tool for Mutual Funds Performance Evaluation. International Business Research, 7(10), 16-21.

Treynor, J. L. (1965). How to Rate Management of Investment Funds, Harvard Review, 43(1), 63-75. 